\title{
Research on Influences of Company Features on Audit Fee
}

\author{
Shengnan Wang \\ Management School, Jinan University, Guangzhou, China \\ Email: 454213219@qq.com
}

Received 7 May 2015; accepted 23 May 2015; published 27 May 2015

Copyright (C 2015 by author and Scientific Research Publishing Inc. This work is licensed under the Creative Commons Attribution International License (CC BY). http://creativecommons.org/licenses/by/4.0/

c) (i) Open Access

\begin{abstract}
This paper mainly considers key factors in company governance and profit management based on the company scale and finance risk. The empirical analysis indicates that higher company governance level can reduce company agency cost and audit risk, so the audit fee also reduces. It regards the frequent profit and loss as the operable profit of the company, which can measure company profit management level and capability. The empirical analysis indicates that higher company profit management level will increase the uncertain risk, so it will generate higher audit fee. Therefore, it analyzes the company audit fee in two fields and provides reference for preparing the market development strategy.
\end{abstract}

\section{Keywords}

Company Governance, Profit Management, Audit Fee

\section{Introduction}

This paper mainly considers relation between company features and audit fee. The company features include company governance and profit management. The basic issue in company governance is how to make the enterprise managers exert asset's purpose by using the assets of capital suppliers and assume the responsibilities to the capital suppliers. Perfection of the company governance can reduce agency cost and audit fee. The profit management can be observed from the view of contract and finance report. From the view of the contract, when the contract is rigid and incomplete, the profit management is a low-cost method and can protect the company from being affected by the unexpected realistic status. From the view of the finance report, the managers can affect the stock value of the company via profit management, but the profit management may be misused and interests of other parties may be sacrificed to increase self interests [1]. The audit fee is the reward acquired by the audit office from the enterprises receiving audit service in performance of economy responsibility contract. In 
reality, this reward is very subjective. Especially to maximize self interests, the company governance level frequently controls the accounting profits and purchases audit comments from the office, so it not only erodes audit independence, but also increases or reduces audit cost manually. The company governance and profit management should be considered in research on the audit fee [2]. The company governance is the direct factors affecting audit fee and the profit management is the potential factor affecting audit fee.

\section{Reference Review and Research Assumptions}

Company governance-no uniform comments are reached on influence of independent director scale on the audit fee. E.g. foreign scholars such as Ferdinand A.Gul (1998) [3], Sahlstron (2004), Sullivan(2000) and domestic scholars such as Liu Minghui, Hu Bo (2006) [4], Zhang Chenyu, Zhao Jing and Xiao Shufang (2007) [5] studied and found that the number of the independent directors is negatively associated with the audit fee, but Cai Jipu (2007) studied it by using data from the listed companies in Shanghai and Shenzhen share A, it found that independent directors do not affect the audit fee charged by the accounting office [6]. Partial scholars think that independent directors can effectively supervise finance reporting process, so it can reduce the audit cost. The domestic scholars have different opinions on relation between consolidation of two posts and audit fee. Cai Jipu (2007) studied and found that consolidation of the board chairman and general manager can reduce the audit fee of the listed companies. Cai Jipu (2007) studied and found that the shareholding ratio of the management level has non-linear relation with the audit fee. Liu Minghui and Hu Bo (2006) studied and found that higher ratio of shares held by the management level in a company will reduce the audit fee. They think that the shares held by the management level improve efficiency and supervision effect of the board of directors and reduce agency cost, risk evaluation level of auditors and audit fee. As a domestic scholar, Cai Jipu (2007) studied and found that the state-owned holding listed companies have higher audit fee compared to non-stated-owned listed companies when an accounting office identifies the audit fee. Liu Minghui and Hu Bo (2006) studied and found no significant correlation between the controller type of the listed companies and audit fee. The influence factors in the above fields belong to research on the audit fee in the company governance.

Company profit management_Liu Bing, Ye Jianzhong, Liao Baoyi (2003) [7], Wu Lina (2004) [8] thought significant positive correlation between the the scale of the audited organization and audit fee. Liu Bing, Ye Jianzhong and Liao Baoyi (2003) studied and found complexity of scale and economy business of the listed companies and the locations of listed companies as the main factor affecting the audit fee of listed companies in China. The stock and total asset, long debt and total asset, profit, audit period and office scale have no important influences on the audit fee. The enterprise asset structure will affect the audit risk. Han Houjun and Zhou Shenchun (2003) [9] studied and found significant correlation of audit expanse and company total asset, subsidiary number, asset debt ratio and audit comments. The audit risk is closely associated with the accounts receivable and stock, so the ratio of accounts receivable and stock to the total asset of the audited organizations will affect the audit fee to certain extent. Simunic (1980) [10] thought that the accounts receivable and stock (customer's asset structure) have significant influence on the audit fee.

Based on the related reference overview and the concept of this paper, the following assumptions are proposed:

Correlation assumption between the board of director and audit fee

H1: The scale ratio of board of directors and independent directors are negatively correlated with the audit fee.

Assumption of power concentration and audit fee

H2: Consolidation of board of chairman and general manager is positively correlated with the audit fee. Separation degree of two rights is positively correlated with the audit fee.

Assumption of correlation between stock right property and audit fee

H3: The company which the governments are the direct controlling shareholders is positively correlated with the audit fee.

Assumption of relation between shareholding ratio of senior executive and audit fee

H4: Share ratio of high management level, shareholding ratio of board of director and the audit fee are negatively correlated.

Assumption of relations between the company scale, profit management capability and audit fee

H5: The company scale is positively correlated with the audit fee of the audited organizations. Non-recurring loss and profit for balancing company profit management is positively correlated with the audit fee. 


\section{Research Sample and Research Design}

\subsection{Research Samples and Data}

2492 listed companies of the share A capital market in 2012 are studied in this paper. The data is from CSMAR database. We delete all financial listed companies in sample selection. These companies are very different from the common companies in data structure. We also delete the missing observations and observations with negative non-recurring losses and profits. Finally 781 data samples are finally identified.

\subsection{Definitions of Main Variables}

The logarithm $\log A F$ of the audit fee of the audited companies is used as the dependent variable. The scale of board of directors, scale and ratio of independent directors, ratio of shares held by senior executive and ratio of shares held by the board of directors, and share concentration are used as the independent variants. Some researches indicate that the nature and ratio of the majority ownership will also affect the company audit fee, so this paper introduces the nature and ratio of the majority ownership into the equation as the independent variants. The above variants are used as the variants of the company governance factors. For the performance indicators reflecting the company profit and loss management level such as sensitive area, accounting and tax difference and non-recurring loss and profit, only the non-recurring profit and loss is selected as the balance indicator due to data collection difficulty. The ratio of stock in total assets, ratio of accounts receivable in total assets and asset debt ratio are used as the control variants to measure the company financial risk. For specific variants, refer to the Table 1. The audit fee, scale of board of director, scale of independent directors, ratio of independent directors, ratio of senior executive share, ratio of shares of board of directors, stock right concentration, total assets and ratio of stock in total assets, non-recurring losses and profits, ratio of accounts receivable in total set and debt ratio of asset are identified according to actual data. If the direct controlling shareholders are government and consolidation of two posts, the variable value equals to 1 , otherwise it equals to 0 . The stock right concentration is measured by the share ratio of top five shareholders.

\subsection{Research Design}

According to assumptions in this paper, we will establish the following regression model to analyze influences of the company governance variants and profit management variant on the audit fee based on the above analysis.

Table 1. Variant definition.

\begin{tabular}{|c|c|c|}
\hline Variant nature & Variant name & Variant explanation \\
\hline \multirow[t]{5}{*}{ Explained variant } & $\log A F$ & Logarithm of audit fee \\
\hline & SBD & Scale of board of director \\
\hline & ID & Scale of independent directors \\
\hline & IDP & Ratio of independent directors \\
\hline & SR & Separation of two rights \\
\hline \multirow[t]{7}{*}{ Explaining variants } & CR & Concentration of ownership \\
\hline & DS & Consolidation of two rights or not \\
\hline & SSH & Shareholding ratio of senior executive \\
\hline & $\mathrm{MSH}$ & Shareholding ratio of board of directors \\
\hline & $\mathrm{DCSH}$ & Nature of direct controlling shareholders and ratio of controlling share ratio \\
\hline & Lnsize & Scale of audited company \\
\hline & IR & Ratio of stock in total asset \\
\hline \multirow[t]{3}{*}{ Control variant } & RR & Ratio of accounts receivable in total asset \\
\hline & Lev & Asset-liability ratio \\
\hline & NPL & Non-recurring loss and profit \\
\hline
\end{tabular}




$$
\begin{aligned}
\log A F= & \beta_{0}+\beta_{1} S B D+\beta_{2} I D+\beta_{3} I D P+\beta_{4} S R+\beta_{5} C R+\beta_{6} D S+\beta_{7} S S H+\beta_{8} M S H \\
& +\beta_{9} D C S H+\beta_{10} L \text { nsize }+\beta_{11} I R+\beta_{12} R R+\beta_{13} L e v+\beta_{14} N P L+\varepsilon
\end{aligned}
$$

\section{Empirical Results and Analysis}

\subsection{Descriptive Statistics}

Table 2 summarizes the descriptive statistics of the variants.

Correlation inspection is performed on the related indicators of the reserved samples such as the audit fee. The results are shown as Table 3 . The explaining variants are significantly correlated, which indicates that they may have severe multiple common-linearity issue. This issue will finally affect the correlation and related directions between them and audit fee.

\subsection{Regression Results and Analysis}

23 sample observation values in which the audit fee and non-recurring loss and profit is 1 and the sample values are abnormal. 791 sample data are residual. VIF values of the variants are computed via the software and the variant SBD which expansion is over 10 are eliminated. Multiplication item DCSH is taken. Based on the regression results, we can know that the variant "scale of board of director" is eliminated in the step 1 . The variants such as "ratio of independent directors", "shareholding ratio of board of directors" and "share ratio of senior executive" are eliminated in the step 2. The variants such as "consolidation of two posts or not", "stock right separation degree" and "stock right concentration" are eliminated in the step 3. The "ratio of stock in total asset" is eliminated. The variant "ratio of accounts receivable in total asset" is eliminated in the step 5 . Finally the variant "asset debt ratio" is eliminated in the final step. With multiple step regression, multiple common-linear issue is eliminated. Only regression results for the final step are listed due to limited space. The regression equation is:

$$
\log A F=12.849-0.071 I D+0.172 C R+0.098 D C S H+(3.39 E-1) L \text { nsize }+(4.69 E-10) X_{15}
$$

Based on the parameters obtained in the empirical results, as shown in Table 4, the adjusted $\mathrm{R}^{2}$ is equal to

\begin{tabular}{|c|c|c|c|c|c|c|}
\hline Variables & Obs & Mean & Std & Min & Median & Max \\
\hline $\log Y$ & 781 & 13.4216 & 0.6804 & 9.2103 & 13.3046 & 19.1482 \\
\hline SBD & 781 & 9.0286 & 1.8672 & 5.0000 & 9.0000 & 18.0000 \\
\hline ID & 781 & 3.2889 & 0.6727 & 2.0000 & 3.0000 & 7.0000 \\
\hline IDP & 781 & 0.3684 & 0.0546 & 0.2222 & 0.3333 & 0.7142 \\
\hline SR & 781 & 0.0466 & 0.0768 & 0 & 0 & 0.4017 \\
\hline CR & 781 & 0.3185 & 0.2271 & 0.0034 & 0.3029 & 0.9731 \\
\hline DS & 781 & 0.2191 & 0.4139 & 0 & 0 & 1.0000 \\
\hline SSH & 781 & 0.0971 & 0.1863 & 0 & 0.0000407 & 0.7907 \\
\hline $\mathrm{MSH}$ & 781 & 0.3734 & 0.1661 & 0 & 0.3622 & 0.8185 \\
\hline DCSH & 781 & 0.0703 & 0.1685 & 0 & 0 & 0.8185 \\
\hline LNSIZE & 781 & 21.105 & 0.966 & 18.960 & 21.007 & 23.885 \\
\hline IR & 781 & 0.1645 & 0.1601 & 0 & 0.1277 & 0.8853 \\
\hline $\mathrm{RR}$ & 781 & 0.1006 & 0.0989 & 0 & 0.0693 & 0.5981 \\
\hline LEV & 781 & 0.4562 & 0.3504 & 0.0164 & 0.4537 & 7.9952 \\
\hline NPL & 781 & 73457844.32 & 270364790 & 2657.80 & 15433532.2 & 5667000000 \\
\hline
\end{tabular}
0.3061. The significant Sig value is 0.00. It indicates better model fitting and regression effect. The regression

Table 2. Descriptive statistics.

Remark: All continuous variables under $1 \%$ level are truncated. 
Table 3. Correction inspection.

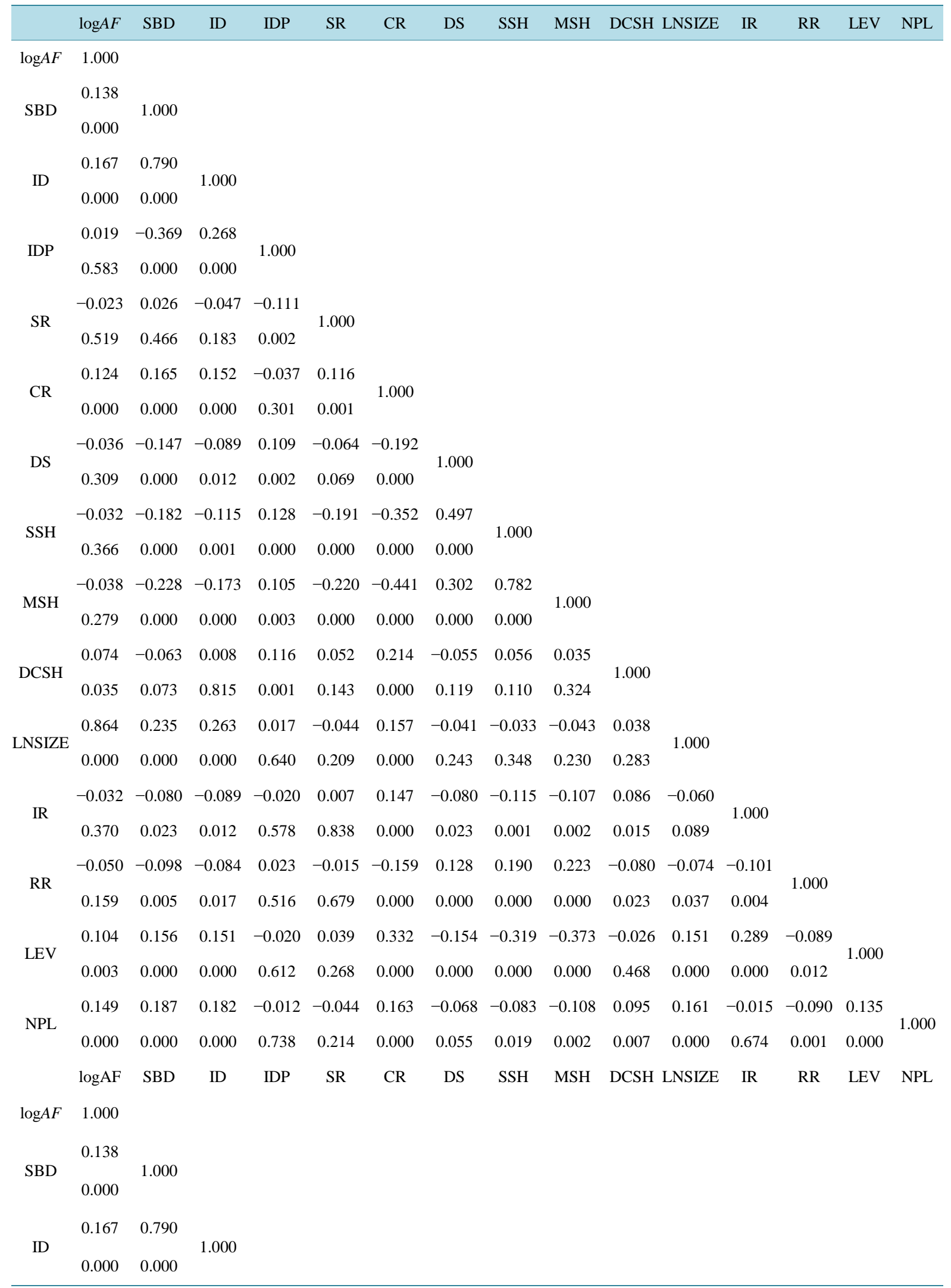




\section{Continued}

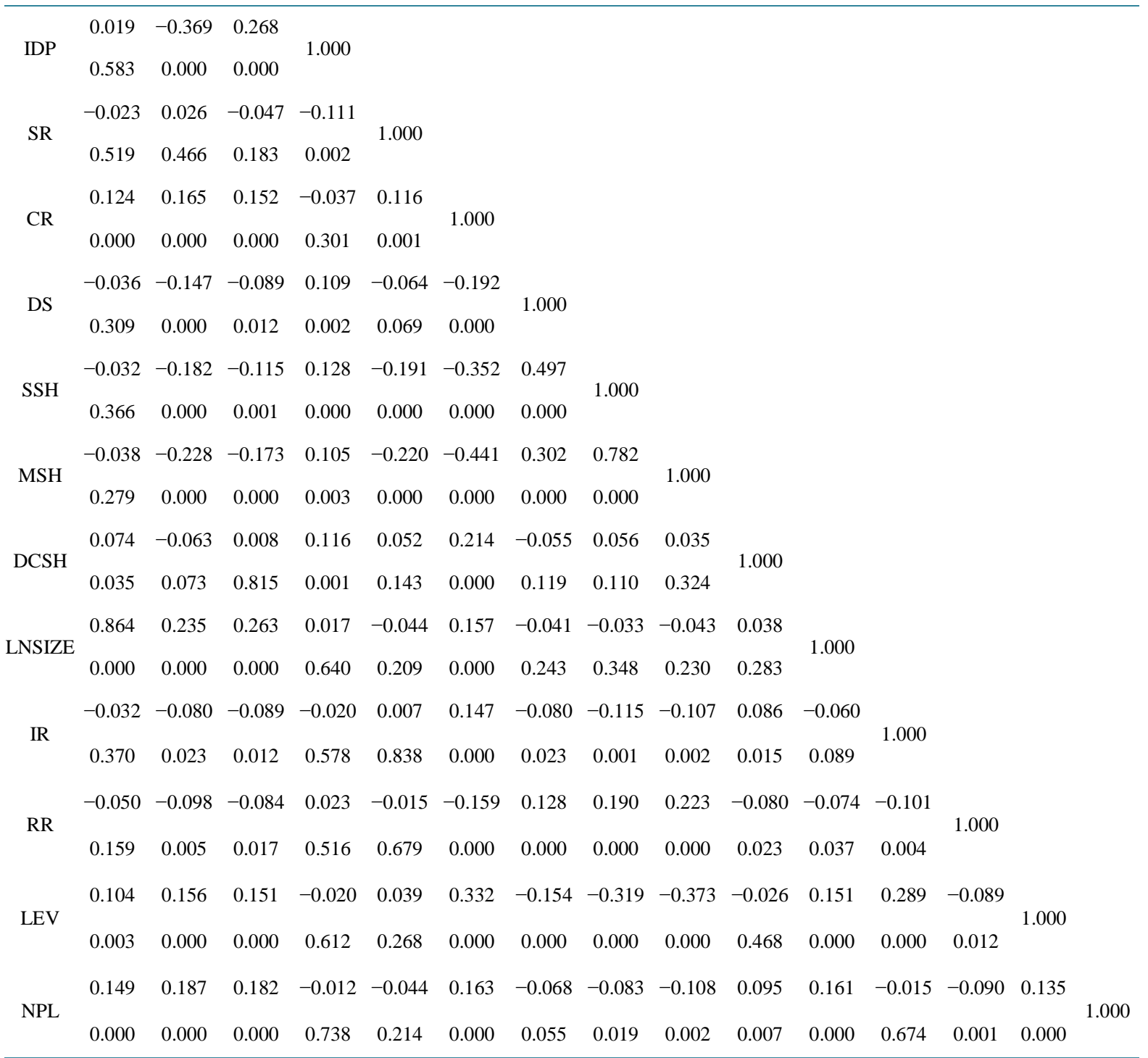

Table 4. Empirical results and inspection.

\begin{tabular}{|c|c|c|c|c|c|c|c|c|}
\hline & ID & CR & DCSH & LNSIZE & NPL & Intercept & $\mathrm{R}^{2}$ & Adj. $R^{2}$ \\
\hline $\log A F$ & $\begin{array}{l}-0.0712 \\
(2.76)^{* * *}\end{array}$ & $\begin{array}{l}0.1721 \\
(2.53)^{* * *}\end{array}$ & $0.098(1.05)$ & $\begin{array}{l}3.39 \mathrm{E}-11 \\
(11.95)^{* * *}\end{array}$ & $\begin{array}{c}4.689 \mathrm{E}-10 \\
(2.10)^{* * *}\end{array}$ & $\begin{array}{c}12.849 \\
(15.05)^{* * *}\end{array}$ & 0.3111 & 0.3061 \\
\hline
\end{tabular}

White inspection

Chi-Square

CSR F inspection of heteroscedasticity correction

$P$ value
$25.17^{* * *}$

0.39

0.5093

Normal assumption inspection

the Cook's D \& DFITS

Yes

Distribution independent inspection 
results indicate that the scales of the independent directors of the audited companies are significantly negative correlated with the audit fee, so the assumption 1 is verified. It indicates that higher scale of the independent board of director will realize better supervision and reduce the agency cost and audit fee. In addition, the empirical analysis results indicate that the stock right concentration, asset scale and audit are significantly correlated with the audit fee, which further verifies correctness of the assumption 2. If the direct controlling shareholder is the government and shareholding ratio have no significant influences on the audit fee. It indicates that the assumption 3 is not verified. In addition, the above analysis results indicate that the share ratio of board of directors and share ratio of senior executive will not generate the significant influences on the audit fee, so the assumption 4 is rejected. The above influence factors belong to research on the audit fee in the company governance. It indicates that higher company governance level can reduce the related audit fee. This paper uses the non-recurring loss and profit as the capability and preference of the company profit management and thinks that the non-recurring loss and profit is significantly correlated with the audit fee. This results also validates the assumption 5 .

\section{Research Contribution}

This paper studies influence of the company features on the audit fee in company governance and profit management. Company governance has direct influence on the audit fee and potential influences on the profit management, so it uses the related indicators of the company governance as the independent variant and related indicators of the profit management as the dependent variants. The research proof of this paper can contribute to better understanding on the related standards of a company in audit fee determination and provide related basis for improving company governance and reducing the audit fee.

\section{References}

[1] Cao, Q., Pu, H., Yang, Y.F. and Liu, C.Y. (2013) Earnings Management, Audit Fee and Audit Opinion. Audit Research, 172, 76-83.

[2] Leventis, S. and Dimitropoulos, P.E. (2010) Audit Pricing, Quality of Earnings and Board Independence: The Case of the Athens Stock Exchange. Advances in Accounting, incorporating Advances in International Accounting, 26, 325332.

[3] GulK, F.A. (1998) A Test of the Free Cash Flow and Debt Monitoring Hypotheses: Evidence from Audit Pricing. Journal of Accounting \& Economics, 15, 167-192.

[4] Liu, M.H. and Hu, B. (2006) Company Governance, Agency Cost and Audit Pricing. Research on finance and Economics, 267, 72-79.

[5] Zhang, C.-Y., Zhao, J. and Xiao, S.F. (2007) Empirical Analysis of Listed Companies Audit Fees. Journal of Applied of Statistics and Management, 152, 1085-1090.

[6] Cai, J.P. (2007) Research on Relation among Company Governance, Audit Risk and Audit Fee. Audit Research, 133, 65-71.

[7] Liu, B., Ye, J.Z. and Liao, Y.Y. (2003) Empirical Research of Audit Fee Influence Factors of Listed Companies in China. Audit Research, 106, 44-47.

[8] Wu, L.N. (2003) Analysis on Influence of Profit Management to the Audit Fee. Accounting research, 194, 39-44.

[9] Han, H.J. and Zhou, S.C. (2003) China Stock Market Accountant Reward Research. Management World, 125, 15-22.

[10] Simunic, D.A. (1980) The Pricing of Audit Services: Theory and Evidence. Journal of Accounting Research, 23, 183226. 